
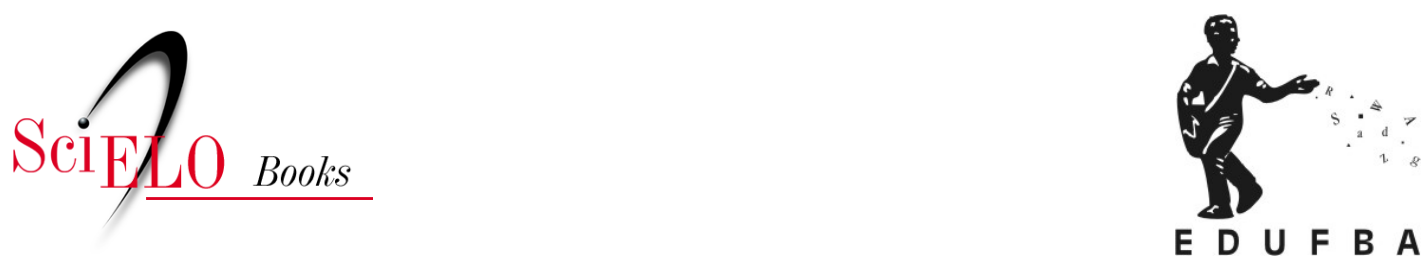

\title{
Parte 1 - Do CachoeiraDoc A falta que me faz: as particularidades do CachoeiraDoc dentro da nova configuração de festivais brasileiros
}

Adriano Ramalho Garrett

\section{SciELO Books / SciELO Livros / SciELO Libros}

GARRET, A. R. A falta que me faz: as particularidades do CachoeiraDoc dentro da nova configuração de festivais brasileiros. In: CESAR, A., MARQUES, A. R., PIMENTA, F., COSTA, L., eds. Desaguar em cinema: documentário, memória e ação com o CachoeiraDoc [online]. Salvador: EDUFBA, 2020, pp. 43-58. ISBN: 978-65-5630-192-1. https://doi.org/10.7476/9786556301921.0003.

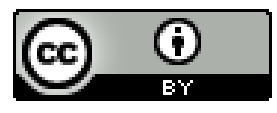

All the contents of this work, except where otherwise noted, is licensed under a Creative Commons Attribution 4.0 International license.

Todo o conteúdo deste trabalho, exceto quando houver ressalva, é publicado sob a licença Creative Commons Atribição 4.0.

Todo el contenido de esta obra, excepto donde se indique lo contrario, está bajo licencia de la licencia Creative Commons Reconocimento 4.0. 


\title{
A falta que me faz: as particularidades do CachoeiraDoc dentro da nova configuração de festivais brasileiros
}

\author{
Adriano Ramalho Garrett
}

Em 2009, um ano antes da criação do CachoeiraDoc: Festival de Documentários de Cachoeira, foram realizados 243 festivais de cinema com proposta de periodicidade regular no Brasil, segundo levantamento do Fórum Nacional dos Organizadores de Eventos Audiovisuais Brasileiros (também conhecido apenas como Fórum dos Festivais). Em 1999, esse número era de apenas 38 eventos. Ou seja: em uma década, houve um aumento de mais de $500 \%$ nessa estatística. (LEAL; MATTOS, 2011, p. 22)

Esse boom dos festivais brasileiros tem como motivo mais evidente o grande crescimento da produção cinematográfica do país tanto em números absolutos quanto em termos de diversidade (geográfica, estética, temática, social, racial/ étnica e/ou de gênero).

Se tomarmos como exemplo o mais antigo evento do tipo no Brasil, o Festival de Brasília, no ano 2000 o número de 22 longas submetidos à comissão de seleção era apontado como um recorde pela imprensa. (FESTIVAL..., 2000) Tal dado saltou para 36 em 2010 e chegou a 150 longas-metragens inscritos em 2018.Com os curtas-metragens a situação é semelhante. Se nos anos 1990 era possível que um único evento - o Curta Kinoforum: Festival Internacional de Curtas-Metragens de São Paulo - exibisse em algumas de suas primeiras edições todos os filmes do formato produzidos no Brasil no período de um ano (CARVALHOSA, 2014), hoje em dia isso seria inviável, pois centenas de curtas são submetidos aos principais festivais a cada ano (em 2019, o Curta Kinoforum recebeu 704 inscrições de curtas-metragens brasileiros).

Entre os fatores definidores para esse cenário em transformação estão o barateamento dos processos de produção e pós-produção - decorrente do predomínio da tecnologia digital ante a analógica -; a criação da Agência Nacional do 
Cinema (Ancine), em 2001; o aumento e a descentralização de recursos públicos destinados à atividade cinematográfica (por meio de editais ou leis de incentivo); e o crescimento, também acompanhado de uma descentralização, da oferta de cursos de formação, tanto universitários quanto de especialização.

Sobre o último aspecto, é possível destacar a criação de cursos de graduação em Cinema e Audiovisual em universidades públicas como a Universidade Estadual do Paraná (Unespar), iniciado em 2005; a Universidade Federal de Santa Catarina (UFSC), em 2005; a Universidade Estadual de Goiás (UEG), em 2006; a Universidade Federal Fluminense (UFF), em 2007; ${ }^{1}$ a Universidade Federal de Pelotas (UFPel), em 2007; 2 a Universidade Federal do Recôncavo da Bahia (UFRB), em 2008; a Universidade Federal de Pernambuco (UFPE), em 2009; a Universidade Federal do Espírito Santo (Ufes), em 2010; e a Universidade Federal do Ceará (UFC), em 2010.Os cursos federais surgem em um contexto de expansão e descentralização dessas universidades pelo governo de Luiz Inácio Lula da Silva (2003-2010). Entre as instituições citadas, a única criada nos anos 2000 foi a UFRB, que surgiu em 2005 com sede na cidade de Cruz das Almas e unidades nos municípios de Amargosa, Cachoeira, Feira de Santana, Santo Amaro e Santo Antônio de Jesus. A criação do curso de Cinema e Audiovisual no Recôncavo da Bahia demandou, por isso, um pensamento não só sobre essa graduação específica, mas sobre o modelo de universidade que começava a ser implantado naquele local.

Entre os festivais de cinema criados e estabelecidos, com destaque no cenário brasileiro a partir dos anos 2000, a particularidade inicial do CachoeiraDoc é justamente ser o único desse grupo a possuir uma relação umbilical com uma universidade local, algo ilustrado pelo fato de o núcleo conceitual do evento ter sido formado em todas as suas edições por professoras da UFRB: Amaranta Cesar (idealizadora, coordenadora e uma das curadoras) e Ana Rosa Marques (coordenadora e uma das curadoras).

1 O curso de Cinema da UFF foi criado em 1968 por Nelson Pereira dos Santos. Contudo, houve uma reformulação completa do currículo em 2005, a qual resultou na criação do curso de Cinema e Audiovisual em 2007. Um ano depois ele passou a ter coordenação própria, distanciando-se do currículo da Comunicação Social.

2 O curso surgiu com o nome de Cinema e Animação em 2007 e formou três gerações de egressos. Depois disso foi desmembrado em dois: bacharelado em Cinema de Animação (2010) e bacharelado em Cinema e Audiovisual (2011). 
Por conta de questões de infraestrutura, as quatro primeiras edições do CachoeiraDoc concentraram suas exibições em espaços dentro do campus universitário, mas a preocupação relativa à formação dos alunos do curso de Cinema e Audiovisual nunca restringiu o evento ao ambiente acadêmico - desde a sua gênese, havia o desejo de se inserir no circuito nacional de festivais. A partir da quinta edição, com a reinauguração do Cine Theatro Cachoeirano, foi ali que passou a ocorrer a grande maioria das sessões do festival.

Uma das marcas do CachoeiraDoc desde seu início é uma conceituação clara, o que resultou em uma estrutura de programação que se repetiu até a sua edição presencial mais recente, em 2017. Fazem parte dessa estrutura mostras competitivas de longas e curtas-metragens brasileiros, oficinas, ciclos de conferências, conversas com realizadores e mostras especiais.

Outro ponto bem demarcado é a forma de lidar com o conceito de documentário. Como conta Amaranta Cesar,

o CachoeiraDoc é irmanado e nasce muito inspirado no forumdoc. $\mathrm{bh},{ }^{3}[\ldots]$ que tem pensado o documentário como esse terreno expandido, mas o tempo todo friccionado e provocado pelo real, e que não perde esse engajamento, ainda que invente formas que sejam diversas, inventivas, e muito próximas inclusive da ficção. [...] Acho que o documentário é um campo fértil porque ele está o tempo inteiro se reinventando. (CESAR, 2017a)

Tal visão é diferente daquela apresentada por um evento como o É Tudo Verdade (ETV), mais antigo festival de documentários do país, que apresenta em sua programação uma concepção menos porosa e mais conservadora sobre o tema. Isso justifica, por exemplo, que alguns dos primeiros trabalhos do cineasta Adirley Queirós (Rap, o canto da Ceilândia e Fora de campo) tenham sido exibidos no ETV, mas que a fabulação proposta por seus longas (A cidade é uma só?, Branco sai preto fica e Era uma vez Brasília) a partir de elementos do real os colocasse fora do escopo curatorial daquele festival, algo que difere das visões do CachoeiraDoc e do forumdoc.bh.

3 Festival do Filme Documentário e Etnográfico, realizado em Belo Horizonte desde 1997. O evento, assim como o CachoeiraDoc, guarda relação íntima com o campo acadêmico, tendo participação de docentes da Universidade Federal de Minas Gerais (UFMG) na idealização e curadoria. 


\section{Os festivais como agentes da identidade e da estabilidade cultural}

Na carta de criação do Fórum dos Festivais, escrita em 2000, explica-se que a entidade nasceu com o objetivo de

fortalecer o circuito brasileiro de eventos audiovisuais, lutar pela melhoria das suas condições de viabilidade, estimular a busca pela excelência na execução de projetos, promover ações de divulgação da importância dos festivais e interagir com todos os segmentos da chamada cadeia produtiva audiovisual. (LEAL, MATTOS, 2007, p. 8)

As expressões “condições de viabilidade”, “execução de projetos”, “ações de divulgação" e "cadeia produtiva audiovisual” servem para ilustrar como o crescimento expressivo de festivais cinematográficos brasileiros a partir dos anos 2000 também está associado ao entendimento deles como um (bom) negócio. Afinal, além de apoiar a cultura, a realização desses eventos, usualmente feita com patrocínios estatais e/ou privados, estimula o turismo e movimenta a economia das cidades e regiões em que os festivais ocorrem.

Entre as centenas de eventos criados, porém, só um grupo bem menor conseguiu atingir repercussão e validação por meio da crítica, de veículos jornalísticos, da academia e/ou do próprio grupo de cineastas.

Para pensar sobre isso é importante deslocar o olhar para além do campo do cinema. Afinal, a produção cinematográfica nunca antes tão volumosa se insere em um contexto global de aumento exponencial na velocidade das inovações técnicas, científicas e culturais. Sobre esse tema, o filósofo alemão Hermann Lübbe escreveu que:

Complementarmente à taxa de inovação aumenta o montante de relíquias históricas e assim, ao mesmo tempo, a quantidade dos bens culturais que para se manterem compreensíveis ou voltarem a ser compreendidos demandam uma explicação especial do ponto de vista metodológico - ou seja, uma explicação histórica. (LÜBBE, 2016, p. 295)

Nas palavras de Andreas Huyssen, outro filósofo alemão que pesquisa as relações entre cultura, memória e história, 
o argumento de Lübbe sobre a contração da extensão do presente aponta para um grande paradoxo: quanto mais o capitalismo de consumo avançado prevalece sobre o passado e o futuro, sugando-os num espaço sincrônico em expansão, mais fraca a sua autocoesão, menor a estabilidade ou a identidade que proporciona aos assuntos contemporâneos. (HUYSSEN, 2000, p. 28)

Tomando essas noções estabelecidas por Huyssen, é possível reivindicar para alguns festivais de cinema o papel de agentes da "estabilidade cultural" e da "identidade cultural”. Afinal, se a existência histórica dos filmes sempre foi em boa medida uma construção da crítica e das curadorias de festivais, no contexto atual, de grande aumento quantitativo da produção audiovisual brasileira, isso ganhou contornos e dimensões novas.

\section{Nova configuração}

Na primeira década dos anos 2000 se consolidou uma percepção de que os festivais considerados tradicionais (Festival do Rio, Mostra Internacional de Cinema de São Paulo, Festival de Gramado e Festival de Brasília) não conseguiam abarcar boa parte da nova produção que estava surgindo no Brasil, devido a um misto de falta de espaço em grade e incompatibilidade conceitual. Isso foi uma motivação central para a criação de novas seções competitivas e novos festivais de cinema.

Entre os eventos precursores desse novo grupo de festivais, vale destacar a Mostra do Filme Livre (MFL), criada em 2002 no Rio de Janeiro, e o Cine Esquema Novo (CEN), que teve a primeira edição em 2003, em Porto Alegre - ambos realizados até hoje. A MFL se diferenciou por apresentar em seus catálogos textos escritos por membros da equipe de curadoria apresentando um panorama conceitual de cada edição e por propor uma ideia ("filme livre”) que se desvencilhava da noção simplória de que os "melhores filmes" eram selecionados. (IKEDA, 2018, p. 113) O CEN, por sua vez, "era quase uma oposição simbólica à diluição que o Festival de Gramado parecia representar”, e tinha como maior particularidade a "destruição das divisões formais entre registro documental e ficção, entre filme-vídeo-digital em prol da experiência fílmica”. (ÁVILA, 2018, p. 160)

Todavia, inclusive por aspectos econômicos/estruturais, a precursora mais bem-sucedida (principalmente em termos de repercussão crítica e jornalística) dentro desse contexto de reconfiguração dos festivais brasileiros foi a Mostra 
Aurora, seção competitiva da Mostra de Cinema de Tiradentes que reúne filmes de cineastas em início de carreira em longas-metragens, criada no ano de 2008. Idealizada pelo crítico e professor Cleber Eduardo, que assumiu a curadoria de longas do evento mineiro um ano antes, a Aurora parte de um entendimento de Cleber a respeito dos filmes inscritos:

[...] o que me chamou atenção foi que parte desses filmes eram trabalhos que eu não via em nenhum outro festival... tipos de filme. Muito baratos, às vezes [feitos] sem edital, com modos de produção completamente diferentes do que estava sendo colocado como modo de produção a ser seguido no Brasil - profissional, que tem uma cadeia toda de processos, desenvolvimento do roteiro, inscrições em laboratórios, participações em editais -, toda uma cadeia previsível e ao mesmo tempo já oficial. (EDUARDO, 2017)

Diferentemente do caso de Tiradentes, outros eventos de renome que surgiram em um período semelhante são realizados em capitais brasileiras e reúnem em comum o fato de terem sido fundados por profissionais (diretores/produtores) da nova geração do cinema brasileiro e trazerem o pensamento de que os festivais que existiam nas suas respectivas cidades eram insuficientes para abarcar a multiplicidade da produção que vinha sendo realizada.

Isso é apontado pela carta de fundação da Semana dos Realizadores:

[...] a verdadeira explosão das tecnologias de produção e difusão de imagens fez com que os festivais do Brasil e do mundo inteiro se vissem inundados por filmes inscritos [...] O fato resultante é que nem aquele que tem sido considerado o maior festival de cinema do Brasil [Festival do Rio] tem mais a possibilidade de dar conta desta verdadeira imensidão daquilo que se produz em audiovisual hoje no país. É com esta constatação, acima de todas, que nasce esta I Semana dos Realizadores. (VALENTE et al., 2009)

Fazem parte deste grupo de festivais, além da Semana dos Realizadores (Rio de Janeiro - fundada por Eduardo Valente, Felipe Bragança, Gustavo Spolidoro, Helvécio Marins Jr., Kléber Mendonça Filho, Lis Kogan e Marina Meliande em 2009) e do já citado CEN, eventos como o Janela Internacional de Cinema (Recife, 
fundado por Emilie Lesclaux e Kleber Mendonça Filho em 2008), o Olhar de Cinema (Curitiba, fundado por Aly Muritiba, Antônio Junior e Marisa Merlo em 2012) e o Fronteira (Goiânia, fundado por Marcela e Henrique Borela em 2014).

O CachoeiraDoc compartilha com esses festivais um interesse marcante por filmes de cineastas que começaram a produzir nos anos 2000 e que apontavam para uma promissora continuidade de carreira (casos de Camilo Cavalcante, Daniel Lisboa, Gabriel Mascaro, Marcelo Caetano, Marcelo Pedroso, Marília Rocha e Maya Da-Rin, para citar apenas nomes que exibiram filmes na primeira edição do festival do Recôncavo Baiano).

Por outro lado, há fatores de diferenciação, dentre os quais é possível destacar: a já levantada relação com o curso universitário; o recorte do cinema documental (algo que não havia em nenhum outro evento no Nordeste brasileiro); a fundação realizada exclusivamente por mulheres; e a localização fora de uma capital brasileira (o que fez com que o evento não surgisse a partir de um descontentamento com o cenário de festivais locais, mas da constatação de que esses espaços não existiam na cidade).

Com relação à Mostra de Cinema de Tiradentes, o CachoeiraDoc tem em comum a localização no interior, em municípios pouco populosos, o que mobiliza as cidades e gera espaços de convivência entre os frequentadores. Todavia, há diferenças notáveis, como essas elencadas por Amaranta Cesar:

Cachoeira é uma cidade de uma herança escravocrata e colonial que não é a herança mineira. É uma herança que deixou mais destruição do que patrimônio. Então essas realidades geram engajamentos diferentes com as cidades. Materialmente também é diferente. A gente realmente é um festival que está na periferia da periferia, em termos orçamentários, em termos geográficos, o que dá engajamentos diferentes. Do mesmo jeito que a incapacidade de definir o que é documentário é aparentemente uma fragilidade, mas no final das contas é também um lugar de força, de potência, acho que talvez a precariedade material da cidade, ou uma estrutura por criar, também gera um engajamento outro, desafiador para todo mundo, pra gente que organiza, pra quem vai, pra própria comunidade. (CESAR, 2017a)

Pensar nos binômios fragilidade/potência e precariedade material/desafio é uma forma de entender o caminho que levou o CachoeiraDoc a se tornar um 
espaço de reflexão reconhecido tanto por cineastas ${ }^{4}$ quanto pela crítica e pela academia, ${ }^{5}$ enquanto outros eventos com orçamentos muito maiores lidam com problemas contínuos de organização e de concepção curatorial. ${ }^{6}$ A falta que me faz, longa-metragem de Marília Rocha exibido na primeira edição do CachoeiraDoc, tem um título ambíguo que pode tanto remeter a uma constatação passiva (tornando-se simplesmente um lamento pela "falta") quanto a uma apropriação ativa (a partir de um entendimento da "falta" como elemento constituinte de si mesmo). No caso do festival baiano a segunda acepção prevalece, sendo a falta (de uma tradição universitária, de um modelo de curso de cinema, de exibições de filmes nacionais e internacionais, de grandes recursos financeiros) explorada como uma potência a ser aproveitada.

\section{A curadoria em evidência}

O grupo formado pelos eventos citados abriu caminho para que se efetivassem discussões mais refinadas sobre a área de programação e curadoria dos festivais de cinema brasileiros, e essa talvez seja a principal zona de convergência entre eles.

Tal foco ganhou evidência recentemente a partir da abertura de espaços para se discutir em público os conceitos e processos de curadoria. Em 2016 o CachoeiraDoc organizou a "Vivência em curadoria da perspectiva das mulheres”, que reuniu um conjunto de curadoras brasileiras para dialogar sobre a atuação das mulheres no cinema brasileiro contemporâneo, com especial atenção

4 Isso pode ser notado, por exemplo, em falas de Marcelo Pedroso (2017) - “[...] enquanto realizador vou querer estar aqui sempre que o CachoeiraDoc selecionar um filme que eu dirigi. Porque é aqui que eu acho que os debates importantes estão acontecendo, sabe? E não é só um debate em si, é toda a construção que o festival faz. O gesto do festival, os filmes que ele prioriza, o tipo de arranjo que ele coloca para a comunidade, o tipo de formação de público que ele faz" - e Adirley Queirós (2015) "[...] eu gosto muito de inscrever meus filmes em Tiradentes e em dois outros festivais: o forumdoc.bh e o Cachoeira Doc." -, em entrevistas ao site Cine Festivais.

5 O festival sediou em 2017 o VI Colóquio Cinema, Estética e Política, organizado pelo Grupo Poéticas da Experiência (programa de pós-graduação em Comunicação Social - PPGCOM da UFMG e Conselho Nacional de Desenvolvimento Científico e Tecnológico - CNPq).

6 Caso do Cine PE, como pontua o crítico Heitor Augusto (2011). 
às áreas de curadoria e programação. ${ }^{7}$ A mesma vivência se repetiu em 2018 no Festival Internacional de Cinema de Realizadoras (Fincar), em Recife. Um ano depois, um encontro com características semelhantes se deu no Encontro de Cinema Negro Zózimo Bulbul, no Rio de Janeiro, que abrigou a imersão em curadoria intitulada "Modos de ver: Curadoria e Descolonização" - em vez de partir do olhar de mulheres, o evento adotou a perspectiva de profissionais negros. Entre 2016 e 2018, reflexões sobre curadoria e programação foram propostas em mesas sediadas pelo Olhar de Cinema: Festival Internacional de Cinema de Curitiba, pela Semana dos Realizadores e pelo Fronteira: Festival Internacional do Filme Documentário e Experimental. Mesmo o campo dos festivais tradicionais foi impactado por essa preocupação, vide a experiência do Festival de Brasília à época da direção artística de Eduardo Valente (2016-2018).

Em entrevista concedida ao site Cine Festivais pouco depois de o Festival de Brasília ter anunciado a sua contratação, Valente explicou a maneira pela qual pretendia montar sua equipe:

Quando aceitei esse convite, deixei claro que minha maior discordância com a metodologia anterior era o fato de que eu acho que curadoria e seleção de filmes é um trabalho específico. [...] Por isso, minha maior proposta para o Festival de Brasília era antes de tudo essa: compor uma comissão plural sim, de pessoas de gerações e regiões diferentes (toda boa comissão deve ter olhares diferentes, para que eles iluminem uns aos outros), mas todos trabalhando de maneira constante com a ideia de curadoria, programação, no máximo crítica (que embora não seja curadoria, pede alguns dos mesmos requisitos, como atualização e conhecimento histórico). E ter um entendimento comum do que acreditam que deveria ser o Festival de Brasília, como ideia. (VALENTE, 2016)

Trazendo outros campos artísticos para o diálogo, é possível apontar que essa fala vai ao encontro de uma transformação de paradigma apontada pelo suíço Hans Ulrich Obrist. Primeiro curador a ser eleito pela revista inglesa Art Review como a pessoa mais influente do campo da arte internacional (em eleição

7 A programação do encontro pode ser acessada pelo link: http://www.cachoeiradoc.com.br/2016/session/vivencia-em-curadoria-da-perspectiva-das-mulheres. 
realizada em 2009), Obrist (2014, p. 36) escreveu em seu livro Caminhos da curadoria que a "expressão 'fazer curadoria', tão comumente usada hoje em dia, foi cunhada no século XX”. Segundo ele, "isso registra uma mudança na compreensão de uma pessoa (um curador) para um projeto (uma curadoria), que hoje é visto como uma atividade em si”. Em outras palavras, "a curadoria é um ofício antigo, mas uma profissão relativamente nova”. (RAMOS, 2010, p. 11)

É importante salientar que a partir dos anos 1980 cresceu de forma significativa, em diferentes áreas, o uso dos termos "curador" e "curadoria”. Esta última palavra é utilizada atualmente no senso comum "como sinônimo de alguém que faz uma seleção especializada e por isso é detentora de uma voz de poder" (CARVALHO, 2017), o que pode levar a uma falsa conclusão de que a curadoria se resume à escolha e exibição de obras de arte, seja de que modo for feita.

Com esse contexto em vista, é possível afirmar que no caso do cinema brasileiro a reflexão contínua, coletiva e sistemática sobre curadoria passou a ser colocada como tema do debate público a partir do século XXI, em grande parte através de alguns festivais e, mais recentemente, de estudos no campo acadêmico.

É importante salientar que as discussões propostas nos últimos anos por meio de debates sobre curadoria nas programações de alguns festivais de cinema não são o começo, mas o desenrolar de um pensamento que, dentro desses eventos, valorizou desde o início a construção de uma concepção particular. Nesse sentido, o pensamento curatorial pode ser construído através do recorte de cada mostra, da seleção de filmes, do modo como eles estão dispostos na grade de programação (seja na ordem das obras de uma única sessão ou com relação à sequência de sessões), da importância dada aos textos do catálogo e da construção de debates/seminários etc.

\section{Particularidades curatoriais}

Seria insuficiente atribuir a expansão de debates públicos a respeito da curadoria em cinema apenas ao surgimento de novos festivais no contexto brasileiro e a discussões curatoriais em geral no contexto mundial. Se, como apontado anteriormente, 2016 foi o ano em que espaços com essas características começaram a surgir em alguns eventos cinematográficos, também é verdade que o cinema não passou incólume pelas discussões trazidas por grupos contra-hegemônicos 
(mulheres, negros, gays, lésbicas, transgêneros, indígenas) em diversos campos da sociedade nessa mesma época. Tendo isso em vista, nada mais natural que os olhares se voltassem também às equipes de curadoria e às suas seleções, ${ }^{8}$ havendo uma demanda objetiva por uma maior diversidade na composição desses grupos. Antes de entrar propriamente no modo como isso tem ocorrido no grupo de festivais já citados, é importante trazer exemplos que mostram como esse contexto reverberou nos festivais mais antigos. A programação desses eventos trouxe uma proliferação de debates sobre e homenagens a minorias de poder, mas geralmente de um modo que oculta a discussão sobre processos curatoriais. Isso é visível no caso do Festival Latino-americano de São Paulo, que em 2016 deu ênfase a produções dirigidas por mulheres (com homenagem a Anna Muylaert) e em 2018 chamou atenção para o cinema feito por pessoas negras (com homenagem a Jeferson De), sem que isso ultrapassasse o caráter de celebração e gerasse impactos em sua práxis curatorial ou na composição de sua equipe de curadoria.

Outro caso semelhante foi o do debate "Representatividade no cinema", ocorrido durante a $41^{\mathrm{a}}$ Mostra Internacional de Cinema de São Paulo, em 2017, após o qual foi exibido o média-metragem Ava Yvy Vera: a terra do povo do raio, dirigido por um coletivo 9 composto por lideranças e jovens do Tekoha Guaiviry (território do povo Guarani e Kaiowá), localizado no Mato Grosso do Sul. Acontece que o filme não constava na programação oficial da mostra e assim o público só poderia saber dessa exibição caso acessasse a agenda do fórum de debates promovido pelo festival. Ao relegar o filme a uma exibição paralela e pouco divulgada, a Mostra de São Paulo se esqueceu de seu próprio papel no sentido de valorizar a representatividade e assim a discussão sobre processos curatoriais e a reflexão sobre o lugar do evento como parte de um mesmo problema permaneceu oculta. Se em casos assim só se notam os olhares a determinado tipo de produção em mesas de debate, no CachoeiraDoc a homenagem feita em sua terceira edição aos 25 anos do Vídeo nas Aldeias - organização fundada por Vincent Carelli que tem entre seus objetivos principais a formação de realizadores indígenas - fez parte de um percurso de atenção à produção cinematográfica

8 Exemplo desse movimento é a pesquisa realizada em 2018 por Cleissa Regina Martins, do Grupo de Estudos Multidisciplinar da Ação Afirmativa (Gemaa), intitulada "Raça e gênero na curadoria e no júri de cinema".

9 Assinam a direção Genito Gomes, Valmir Gonçalves Cabreira, Jhonn Nara Gomes, Jhonatan Gomes, Edina Ximenez, Dulcídio Gomes, Sarah Brites e Joilson Brites. 
sobre, com e/ou por indígenas. Logo na primeira edição, houve as exibições de Kene Yuxí, as voltas do Kene, dirigido por Zezinho Yube, e Espelho nativo, dirigido por Phillipi Bandeira, na mostra competitiva nacional de longas ou médias-metragens. Nessa mesma seção, na edição mais recente do festival (em 2017), o já citado Ava Yvy Vera: a terra do povo do raio foi exibido e ganhou os prêmios dos júris oficial e jovem.

Tendo feito esse preâmbulo, é possível relembrar os debates sobre curadoria e programação ocorridos recentemente em alguns festivais:

- Na Semana dos Realizadores, a mesa "A Semana aberta: caminhos passados, escolhas presentes, possibilidades futuras", ocorrida em novembro de 2016, teve a proposta de abrir ao público interessado os modelos de seleção e programação do festival, apresentando um desejo de mudança que resultou em um processo diferente na edição seguinte, com uma equipe maior e mais diversa;

- No Fronteira, em 2017, não foi propriamente o festival que esteve em debate, mas sim as questões amplas ligadas a curadoria e programação de cinema, através do Ver Cinema: Encontro Internacional de Programadores de Cinema, inédito evento do tipo no país;

- No Olhar de Cinema, mesas sobre "crítica e curadoria" ou "curadoria e programação” acontecem desde 2016. Entre 2017 e 2019 ocorreram mesas de encontro com a equipe de programação com o objetivo de apresentar os filmes selecionados e falar sobre o processo que levou até a escolha deles;

- No Festival de Brasília, as mesas "A curadoria de curtas e médias no tempo do digital", em 2016, e "Curadoria aberta: o processo de montagem da programação do Festival de Brasília”, em 2017 e 2018, tiveram o objetivo de falar sobre o processo curatorial, entrando em questões práticas como a criação de planilhas e a divisão do visionamento em duplas (no caso dos curtas-metragens). Assim como no Olhar de Cinema, elas ocorreram antes das projeções das mostras competitivas.

Tratando especificamente dos dois últimos festivais, o fato de os debates acontecerem antes das exibições é algo que merece reflexão, visto que, se por um lado essas mesas têm mérito por ampliar e desmistificar o debate sobre 
curadoria, por outro é possível que esse formato tenda a manter a equipe de seleção e programação em um lugar de conforto, pois questões concretas suscitadas pelo contato com os filmes nunca serão respondidas (ou ao menos não nesse ambiente oficial).

No caso do CachoeiraDoc não há na programação um encontro específico voltado para discutir a totalidade da seleção apresentada em cada edição, mas um exemplo particular de debate promovido pelo festival foi, como citado anteriormente, a "Vivência em curadoria da perspectiva das mulheres", realizada em 2016.

Seu texto de apresentação dizia o seguinte:

[...] como não suspeitar que a aparente frágil presença de mulheres no cinema brasileiro não se deve também às perspectivas masculinas que estariam imiscuídas aos critérios de valoração dos filmes? Nos perguntamos, então, em que medida a atuação minoritária das mulheres na curadoria e na crítica condiciona os parâmetros de legitimação dos filmes em vigor, bem como a notável negligência crítica em relação às mulheres do/no cinema brasileiro. Assim, a partir da consideração de que a curadoria, instância fundamental para a inscrição dos filmes na História dos cinemas, é uma ação política e perspectivada, a Vivência em curadoria da perspectiva das mulheres levanta e tenta enfrentar a questão: o que podem as mulheres para a legitimação e escritura histórica dos filmes de mulheres e de suas trajetórias? (VIVÊNCIA..., [2016])

O encontro originou a mostra Com Mulheres, feita com curadoria coletiva e que trazia obras que abarcavam tanto a questão da representatividade (filmes de realizadoras) quanto da representação (filmes sobre mulheres). Ou seja: esteve presente nesse processo um forte caráter propositivo desde a formulação do evento, passando pelo modo de organização (não um debate, mas vários, constituindo uma vivência) e chegando à programação de sessões e às exibições do festival, constituindo-se como uma iniciativa inovadora nesse ainda incipiente movimento de atenção às práticas de curadoria em cinema no Brasil.

Nesse sentido, também é importante notar o quanto a realidade sociopolítica brasileira influenciou muitas das discussões curatoriais trazidas pelo 
CachoeiraDoc. Em 2014 e 2015, por exemplo, as principais mostras especiais do festival (uma retrospectiva de filmes do chinês Jia Zhangke e trabalhos oriundos do Laboratório de Etnografia Sensorial da Universidade de Harvard, agrupados na mostra Perspectivas do espaço e imersões sensoriais) se ligavam de um modo menos direto ao contexto nacional, algo que mudou no período que coincidiu com a deposição da presidente eleita Dilma Rousseff. Assim, em 2016 ocorreu a já citada mostra Com Mulheres e em 2017 foi a vez das mostras Memórias de Lutas e Corpos em Lutas, que reuniram filmes de diferentes épocas e países marcados por propostas de intervenção social.

Essas mostras, por sua vez, surgiram de uma percepção - propiciada por uma continuidade de olhar, algo vital para qualquer curadoria - de que desde os marcantes protestos populares de junho de 2013 houve um aumento significativo na produção de "filmes de grupos minoritários comprometidos com a reversão de injustiças e opressões estruturais, produzidos em aliança ou no seio de movimentos sociais" (CESAR, 2107b), e que isso não se refletia em visibilidade no cenário dos festivais brasileiros:

No lugar de pensar nos filmes apenas como obras, estou propondo pensá-los também como gestos, iniciativas, atos. Ou seja, pensá-los em sua dimensão fenomenológica, o que implica em considerar os filmes em sua conexão com a vida, com o extra-campo cinematográfico. Agir curatorialmente desse modo, a partir desse conceito, tem nos levado a olhar de modo renovado para os filmes das minorias, dos outros sujeitos históricos que agora estão a filmar (mulheres, negros, índios, minorias sexuais, etc.), subvertendo parâmetros universalizantes, tentando descolonizar um pouco o nosso olhar. (CESAR, 2107b)

Essas duas iniciativas agem sobre uma realidade do país e complexificam discussões curatoriais em um momento em que elas começam a aparecer com regularidade no campo cinematográfico, e é esse caráter propositivo que coloca o CachoeiraDoc em um lugar de destaque nessa nova configuração de festivais brasileiros. 


\section{Referências}

AUGUSTO, Heitor. O Cine PE 2011 não acabou. Urso de Lata, 12 maio 2011. Disponível em: https://ursodelata.com/2011/05/12/o-cine-pe2011-nao-acabou. Acesso em: 25 set. 2020.

ÁVILA, Alisson. Objetos audiovisuais não identificados. In: MENOTTI, Gabriel (org.). Curadoria, cinema e outros modos de dar a ver. Vitória: Edufes, 2018. p. 160-164.

CARVALHO, Ananda. Qual é o papel da curadoria no contexto da arte contemporânea. Nexo, São Paulo, 3 maio 2017. Disponível em: https:// bit.ly/3jOBzzE . Acesso em: 20 ago. 2019.

CARVALHOSA, Zita. Palco para grandes diretores, Festival de Curtas de São Paulo chega aos 25 anos. [Entrevista concedida a] Adriano Garrett. Cine Festivais, São Paulo, 18 ago. 2014. Disponível em: https:// bit.ly/3mQBwc0. Acesso em: 20 ago. 2019.

CESAR, Amaranta. "Os festivais ainda olham pouco para a produção dos novos sujeitos históricos”. [Entrevista concedida a] Adriano Garrett. Cine Festivais, São Paulo, 20 mar. 2017a. Disponível em: https://bit.ly/32ZKOe1. Acesso em: 20 ago. 2019.

CESAR, Amaranta. VIII CachoeiraDoc relembra passado para pensar cinema engajado no Brasil atual. [Entrevista concedida a] Adriano Garrett. Cine Festivais, São Paulo, 4 set. 2017b. Disponível em: https:// bit.ly/3iOpTvI. Acesso em: 20 ago. 2019.

EDUARDO, Cleber. Mostra Aurora completa dez anos com tendência a radicalizar, diz curador. [Entrevista concedida a] Adriano Garrett. Cine Festivais, São Paulo, 12 jan. 2017. Disponível em: https://bit. ly/3mPtdgQ. Acesso em: 20 ago. 2019.

FESTIVAL de Cinema de Brasília tem 6 filmes na disputa. Terra, São Paulo, 2000. Disponível em: https://bit.ly/3j09QiK. Acesso em: 20 nov. 2019

HUYSSEN, Andreas. Seduzidos pela memória: arquitetura, monumentos, mídia. Rio de Janeiro: Aeroplano, 2000.

IKEDA, Marcelo. Novos desafios na curadoria e programação no cinema brasileiro do século XXI. In: MENOTTI, Gabriel (org.). Curadoria, cinema e outros modos de dar a ver. Vitória: Edufes, 2018. p. 107-116. 
LEAL, Antônio; MATTOS, Tetê (org.). Festivais audiovisuais: diagnóstico setorial 2007: indicadores 2006. [S. l.]: Fórum dos Festivais, 2007. Disponível em: https://bit.ly/3i1agEd. Acesso em: 24 ago. 2019.

LEAL, Antônio; MATTOS, Tetê (org.). Painel setorial dos festivais audiovisuais: indicadores 2007-2008-2009. Rio de Janeiro: Cima, 2011. Disponível em: https://bit.ly/3kK6LUt. Acesso em: 24 ago. 2019. LÜBBE, Hermann. Esquecimento e historicização da memória. Estudos Históricos, Rio de Janeiro, v. 29, n. 57, p. 285-300, jan. 2016. Disponível em: https://bit.ly/306G6sW. Acesso em: 25 ago. 2019. MARTINS, Cleissa Regina. Raça e gênero na curadoria e no júri de cinema. Boletim Gemaa, Niterói, n. 5, 2018. Disponível em: https://bit. ly/2EBnxFY. Acesso em: 25 nov. 2019.

OBRIST, Hans-Ulrich. Caminhos da curadoria. Rio de Janeiro: Cobogó, 2014.

PEDROSO, Marcelo. "Só a partir da escuta é que podemos pensar numa possibilidade de transformação”. [Entrevista concedida a] Adriano Garrett. Cine Festivais, São Paulo, 12 set. 2017. Disponível em: https://bit.ly/2EsEYs3. Acesso em: 10 ago. 2019.

QUEIRÓS, Adirley. Curtas \& Festivais: conheça a carreira do diretor Adirley Queirós. [Entrevista concedida a] Adriano Garrett. Cine Festivais, São Paulo, 20 dez. 2015. Disponível em: https://bit.ly/3j2Q19o. Acesso em: 20 ago. 2019.

RAMOS, Alexandre Dias (org.). Sobre o ofício do curador. Porto Alegre: Zouk, 2010.

VALENTE, Eduardo et al. Carta de fundação da Semana dos Realizadores. [S. l.: s. n.], 2009. Disponível em: https://bit.ly/2FNhrmA. Acesso em: 13 jun. 2018.

VALENTE, Eduardo. Eduardo Valente assume curadoria e traz novas ideias ao Festival de Brasília. [Entrevista concedida a] Adriano Garrett. Cine Festivais, São Paulo, 24 jun. 2016. Disponível em: https://bit. 1y/2HtNhVO. Acesso em: 20 ago. 2019.

VIVÊNCIA em curadoria da perspectiva das mulheres. Cachoeira: CachoeiraDoc, [2016]. Disponível em: https://bit.ly/3i33UUSAcesso em: 23 nov. 2019 


\title{
Política cultural, financiamento e gestão de um festival de cinema
}

\author{
Fernanda Pimenta \\ Leonardo Costa
}

O CachoeiraDoc: Festival de Documentários de Cachoeira teve oito edições periódicas anuais entre 2010 e 2017, na cidade de Cachoeira, no recôncavo da Bahia. Nas oito edições, cerca de 17 mil pessoas assistiram a mais de 345 documentários, muitos deles inéditos na Bahia e no Brasil. O festival buscou promover o intercâmbio de ideias e incentivar que a cidade de Cachoeira e o estado da Bahia articulem-se ao mundo através do cinema. Além dos debates com os realizadores que vinham de todas as regiões do país, foram realizadas 20 oficinas e 26 mesas-redondas. Em 2017, além do festival em Cachoeira, foi realizada a mostra CachoeiraDoc em Movimento, com documentários contemporâneos brasileiros em exibição na Caixa Cultural, em Salvador. Em maio de 2020, em plena pandemia da Covid-19, aconteceu uma edição especial e on-line do festival intitulada “Festival Impossível, Curadoria Provisória”. Em dezembro de 2020, foi realizada a nona edição do CachoeiraDoc, também on-line. Todas as edições foram realizadas pela Ritos Produções, com a coordenação de produção feita pelos seus sócios, ${ }^{1}$ e pela Universidade Federal do Recôncavo da Bahia (UFRB), através da coordenação e curadoria das professoras Amaranta Cesar e Ana Rosa Marques.

Miriam Alencar no livro, de 1978 (p. 55), O cinema em festivais e os caminhos do curta-metragem no Brasil destacou que a importância dos festivais de cinema se dá:

[...] a) pelo que pode e deve revelar de novos valores, novas idéias, novas culturas, através da participação ativa do maior número de países; b) pelo mercado de venda de filmes, que proporciona a comercialização do produto aos mais diversos países; c) porque permite o

1 Renata Rocha, em 2010, e Fernanda Pimenta e Leonardo Costa, de 2010 a 2020. 
contato entre as pessoas, das mais diferentes regiões ou países, que trocam idéias entre si, que travam ou ampliam seu conhecimento do que está se passando no mundo cinematográfico.

Ainda segundo a autora:

Os festivais (cinematográficos) possuem uma série de fatores políticos, econômicos, culturais, sociais, onde governamentalmente transmite-se um ponto de vista de incentivador cultural; para os realizadores é uma janela de exibição; para a sociedade é uma forma de acesso à cultura; para investidores é uma chance de atrelar sua marca à imagem do festival, em contato direto com o público, além de serem partes importantes da cadeia produtiva cinematográfica. (ALENCAR, 1978, p. 44)

Essas reflexões de Alencar, embora antigas, continuam sendo válidas até hoje para falarmos sobre um festival de cinema. Neste artigo buscamos abordar brevemente a trajetória, do ponto de vista de quem realiza um festival, envolvendo os processos de financiamento, produção e gestão do CachoeiraDoc, cuja principal relevância está em propiciar encontros entre filmes e pessoas numa cidade na periferia do Brasil. Não podemos narrar esses fatos sem uma conexão com as políticas culturais para o setor do audiovisual, algo importante para o desenvolvimento do mercado e da área do cinema.

\section{Políticas para o audiovisual}

Quais são as condições de produção do cinema? Que políticas são dedicadas a tratar do setor na atualidade? Qual o papel da União, dos estados e dos municípios nesse processo?

Numa narrativa histórica mais ampla sobre as políticas audiovisuais no Brasil podemos perceber como a esfera nacional tem, em grande medida, maior participação nesse processo, o que não exclui a importância de ações e políticas pensadas e gestadas pelos governos estaduais e mesmo municipais.

Os profissionais do campo audiovisual participam como propositores e grupo de pressão para a criação e fiscalização de políticas. "As iniciativas do Ministério da Cultura em relação ao audiovisual contaram com a participação 
dos profissionais do cinema desde sua elaboração e têm adquirido importância fundamental para o desenvolvimento do setor". (BEZERRA; ROCHA, 2012, p. 131) Embates entre Estado, realizadores e empresários do setor criaram condições para o desenvolvimento de políticas para o segmento, indo além do fomento apenas de um dos elos da cadeia produtiva, através do estímulo da produção de filmes. Diversas ações e instrumentos foram criados:

\begin{abstract}
[...] legislação específica para o setor, criação de condições para a formação de público e estabelecimento do produto nacional no mercado (tome-se como exemplo a Cota de Tela - percentual de dias ou número de filmes nacionais no circuito exibidor - ou a isenção fiscal para distribuidoras estrangeiras tornarem-se investidoras da produção cinematográfica brasileira), o sistema de incentivo fiscal, instituições e demais instrumentos de intervenção, dentre as quais situamos como mais emblemáticas a Embrafilme (criada em 1969, durante o Regime Militar, como produtora e depois também distribuidora de filmes nacionais) e, mais recentemente, a Ancine (Agência Nacional do Cinema). (COSTA, 2013, p. 132)
\end{abstract}

Interessante notar como a noção das tristes tradições (ausência, autoritarismo e instabilidade) das políticas culturais no Brasil, apontada por Rubim (2007), também reverbera no setor audiovisual. Na passagem anterior vemos como durante o regime militar (1964-1985) a criação da Embrafilme reforça a triste tradição de forte intervenção do Estado no campo cultural em períodos autoritários. Nessa época a produção de filmes nacionais foi bem sucedida, ao passo que, em momentos democráticos, nem sempre tivemos a mesma força para criar ou manter políticas específicas na área cultural, como foi, em especial, o caso do governo de Fernando Collor (1991-1992):

\footnotetext{
A atuação dos estados e municípios brasileiros na atividade cinematográfica se faz presente para preencher uma lacuna deixada pela ausência total dos órgãos, instituições e marcos regulatórios nacionais, quando do governo do então presidente Fernando Collor (1991-92). Concine (Conselho Nacional de Cinema), Embrafilme, Cotas de Tela e o próprio Ministério da Cultura foram extintos, desmantelando um conjunto de fatores que, embora não fosse totalmente eficiente, viabilizavam a existência do Cinema Brasileiro. (COSTA, 2013, p. 133)
} 
O estímulo à regionalização, entretanto, não foi feito na Bahia do mesmo modo que em outros estados, como aponta o estudo: “[...] a regionalização estimulava o surgimento de centros regionais de produção, como, por exemplo, os polos surgidos no Espírito Santo, no Rio Grande do Sul e em Pernambuco”. (MARSON, 2006, p. 54)

"A situação do audiovisual em Pernambuco difere dos demais estados do Nordeste, onde não identificamos ambientes igualmente privilegiados”. (COSTA, 2013, p. 134) Ou seja, num momento de instabilidade das políticas culturais, como no governo Collor, alguns estados, como a Bahia, enfrentaram esse vazio na criação de políticas para o setor.

O governo de Itamar Franco, sucessor de Collor, inicia uma retomada do cinema nacional, estimulando a participação de empresas privadas através, principalmente, do incentivo fiscal ${ }^{2}$ na atividade de produção, que terá continuidade nos dois mandatos de Fernando Henrique Cardoso (FHC). Só com o governo Lula (2003-2010) há uma consolidação das políticas para reestruturação da cadeia produtiva do audiovisual focando na produção dos filmes, mas também na difusão, formação, memória e política externa. Medidas para a descentralização da produção, fortemente concentrada no eixo Rio-São Paulo, foram iniciadas. Além da inclusão de grupos sociais até então excluídos das políticas para área.

O número de filmes lançados aumenta nesse período. Em 2002 foram 29 títulos e em 2013 foram 129. A produção documental também aumentou muito:

No ano 2000, os documentários representaram quase $20 \%$ dos lançamentos nacionais. Nos anos seguintes, a onda de documentários nos cinemas cresceu, a ponto de atingir, no final de 2004 mais de $30 \%$ dos lançamentos nacionais em salas de cinema. (RAVICZ, 2005, p. 34)

A ampliação do circuito dos festivais está diretamente vinculada ao aumento da produção audiovisual no país, a partir da chamada retomada do cinema nacional em 1995 e em especial a partir de 2003, com políticas de incentivos específicas criadas nos governos Lula e Dilma.

2 Em 1993, por pressão dos produtores de cinema, o governo de Itamar Franco criou a Lei do Audiovisual (Lei $\left.n^{\circ} 8.685 / 1993\right)$, na qual a empresa financiadora não precisava entrar com nenhum percentual de recursos próprios, patrocinava os filmes com recursos que iriam para o imposto de renda. 
No caso das políticas para difusão do audiovisual, mais estritamente no caso das mostras e festivais, a Bahia tem tradição, e corrobora o panorama nacional de crescimento dos eventos nos anos 2000. Tamara Chéquer Cotrim (2017), na sua dissertação de mestrado sobre festivais e mostras de cinema na Bahia contemporânea nos conta que o primeiro evento de que se tem notícia no país aconteceu em Salvador em 1951, o Primeiro Festival de Cinema da Brasil, por iniciativa de Walter da Silveira e Carlos Coqueijo Costa. Em 1962, aconteceu o Primeiro Festival de Cinema da Bahia, com lançamento de Tocaia no asfalto, de Roberto Pires. Mas foi com a Jornada de Cinema da Bahia, que a Bahia se tornou parte do circuito de festivais. A primeira jornada aconteceu em Salvador em 1972 e a última (40a edição) em 2013. Foi um dos mais antigos e longínquos festivais do país.

Na década de 1990, com a maior facilidade de produção de vídeos, nasceu em Salvador, em 1994, outro festival longevo: o Festival Nacional de Vídeo Imagem em 5 Minutos. Organizado pela Fundação Cultural do Estado da Bahia (Funceb), ${ }^{3}$ o evento reunia realizadores experientes e iniciantes, oriundos das mais diversas localidades do país, e exibia produtos em vídeo com até cinco minutos de duração. Foram ao todo 16 edições (em 21 anos, não aconteceu em 2001, 2002, 2006, 2010, 2013).

Tamara Chéquer Cotrim ressalta:

Os anos 2000 foram bastante significativos no que diz respeito aos festivais e mostras de cinema. Foi no decorrer desses anos que houve uma expansão no número de eventos de exibição nunca antes vista, com festivais e mostras acontecendo em diversos lugares do país, realizados sob as bases de um contexto social específico, aliás, bastante propício, uma vez que, estavam se destacando como importantes para a estruturação da cadeia do cinema e audiovisual brasileiro, sobretudo em decorrência do crescimento da produção. Inclusive com reconhecimento do governo como importantes para àquela seara, merecendo incentivos financeiros públicos para acontecerem. (COTRIM, 2017, p. 26)

Em 2002, foi realizado o primeiro Panorama Internacional Coisa de Cinema, que até o ano de 2019 teve 15 edições: não aconteceu em 2006 e 2008. A primeira

3 Também criada no período do regime militar, em 1974. 
Mostra de Cinema Conquista, na cidade de Vitória da Conquista, sudoeste baiano, aconteceu em 2004 e, em 16 anos, contou com 14 edições: não foi realizada em 2005 e 2016. Em 2005, ocorreu o primeiro Seminário Internacional de Cinema da Bahia, que depois passou a se chamar Cine Futuro. ${ }^{4} \mathrm{O}$ último ano do evento foi em 2015. Em 11 anos, ele não aconteceu em 2013 e em 2014. E em 2010, foi realizado o primeiro CachoeiraDoc: Festival de Documentários de Cachoeira, que em dez anos teve oito edições - à exceção dos anos de 2018 e 2019, retornando em 2020.

Todos os citados são os festivais de maior notoriedade e continuidade na Bahia ao longo de décadas e têm em comum a interrupção das edições. Eles começaram pequenos e recebiam apoio de instituições como universidades, prefeituras e outras instituições capazes de fornecer estrutura ou mão de obra, e foram crescendo aos poucos, tendo cada vez mais recursos públicos. Devido à descontinuidade ${ }^{5}$ de políticas culturais acabam sendo interrompidos.

Apesar das políticas culturais de territorialização criadas a partir de 2007, com o governo Jaques Wagner na Bahia, que buscou descentralizar e democratizar a formulação, o planejamento e a execução de programas e ações culturais, levando-os para o interior do estado, as mostras e os festivais de cinema ainda estão concentrados na capital. Em 2017, segundo o documento Os festivais audiovisuais brasileiros em 2017: geografia e virtualização, de Paulo Vitor Luz Corrêa, a Bahia teve 14 mostras e festivais. Destes, nove aconteceram em Salvador e Região Metropolitana. Abaixo pode ser visto um resumo da Bahia (CORRÊA, 2018, p. 53) (Figura 1).

Os três festivais citados na Figura 1 que aconteceram em 2017 na cidade de Cachoeira foram o CineVirada: Festival de Cinema Universitário da Bahia; o CachoeiraDoc: Festival de Documentários de Cachoeira; e o Panorama Internacional Coisa de Cinema (que aconteceu em Salvador e Cachoeira). A implantação do curso de cinema em Cachoeira tem relação com a existência destes e outros ${ }^{6}$ eventos na cidade e no estado e faz parte das políticas federais de

4 Disponível em: http://seminariodecinema.blogspot.com/p/o-festival.html. Acesso em: 18 abr. 2019.

5 Uma das tristes tradições colocadas por Rubim (2007), a instabilidade das políticas culturais.

6 Grupos da universidade como o PET Cinema UFRB e o Cineclube Mário Gusmão fazem algumas mostras. Em 2018, um aluno do curso de Cinema e Audiovisual (UFRB) iniciou o Festival Mimoso de Cinema em sua cidade natal (Luis Eduardo Magalhães). Em 2019, surge a MAR (Mulheres Ativismo Realização) em Cachoeira, criada por egressas (UFRB). 
Capital do estado,

com pelo menos 1 festival

O Outras cidades,

com pelo menos 1 festival

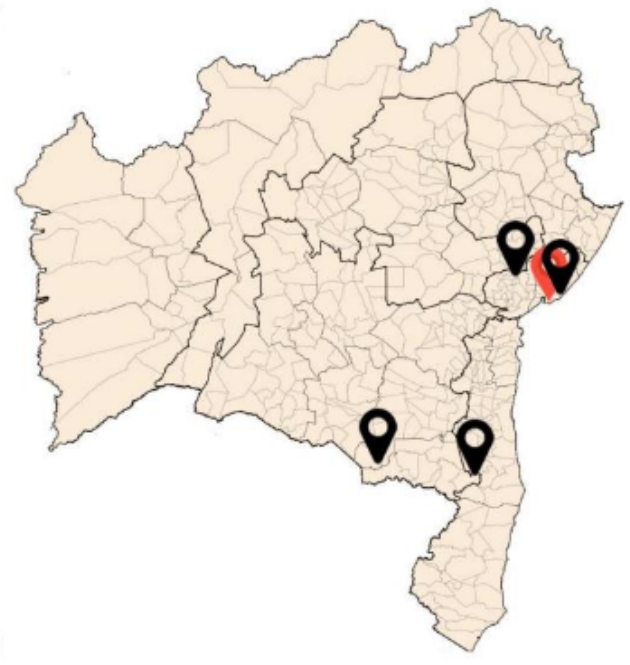

\begin{tabular}{|c|c|}
\hline Municíio & $\begin{array}{c}\text { Quantidade } \\
\text { de Festivais }\end{array}$ \\
\hline Salvador & 7 \\
\hline Vitória da Conquista & 2 \\
\hline Cachoeira & 2 \\
\hline $\begin{array}{c}\text { Salvador e Cachoeira } \\
\text { (Intermunicipal) }\end{array}$ & 1 \\
\hline Lauro de Freitas & 1 \\
\hline Pau B rasil & 1 \\
\hline TOT AL & $\mathbf{1 4}$ \\
\hline
\end{tabular}

\begin{tabular}{|c|c|}
\hline \multicolumn{2}{|c|}{ BAHIA } \\
\hline Total de municipios no estado & 417 \\
\hline Total de festivais no estado & 14 \\
\hline Muricípios com festival & 5 \\
\hline $\begin{array}{c}\text { Percentual dos municipios que sediam festival no } \\
\text { estado }\end{array}$ & $\sim 1,1 \%$ \\
\hline
\end{tabular}

Figura 1 - Localização dos festivais audiovisuais na Bahia

Fonte: Corrêa (2018, p. 53). 
territorialização do setor audiovisual. Entre 2005 e 2012, foram criadas 18 novas universidades e institutos federais e 173 campus universitários. Em 2005, foi implantada a UFRB, que hoje conta com sete centros de ensino em seis cidades do Recôncavo. Em 2008, foi feito o primeiro vestibular para o curso de Cinema e Audiovisual, que inicialmente tinha "ênfase em documentário".

O projeto pedagógico diz que a criação do curso

É parte do processo de retomada do cinema brasileiro, e de toda a área do audiovisual no país, e, também, participa do esforço para colocar o Estado da Bahia na dimensão real da sua importância na história do cinema brasileiro, oferecendo a possibilidade de uma formação qualificada para os profissionais desta área da comunicação. (UFRB, [200-], p. 7)

Nesse contexto, nasce a vontade de colocar a cidade de Cachoeira como parte do circuito alternativo de exibições do país.

\section{Financiamento do CachoeiraDoc}

O governo de Jaques Wagner na Bahia (2007 a 2014), com Márcio Meirelles e Albino Rubim como secretários de Cultura, implantou políticas culturais na Bahia baseada nas políticas federais dos ministros da Cultura Gilberto Gil e Juca Ferreira. Houve valorização do Fundo de Cultura, criado em 2005. "Entre 2007 e 2013, o Fundo de Cultura do Estado da Bahia aumentou seus recursos em 164\%. [...] Tão importante quanto o aumento de recursos, foram os novos procedimentos democráticos e republicanos do Fundo [...]”. (RUBIM, 2015) Os anos de 2007 e 2008 foram de adaptação dos funcionários da Secretaria de Cultura, que estavam se adequando à crescente demanda dos proponentes, que ainda não sabiam elaborar projetos culturais ou geri-los. Nesses anos o número de inscritos foi baixo, em especial, no interior do estado. A Funceb realizou workshops de elaboração em projetos culturais em todos os territórios de identidade e a partir de 2009 o resultado pode ser visto, com crescimento do número de inscritos e diminuição da concentração na Região Metropolitana de Salvador. (LIMA, 2011)

Em 2009 o CachoeiraDoc concorreu pela primeira vez e foi contemplado no Edital de Apoio à Realização de Mostras e Festivais Audiovisuais (no 21/2009), ${ }^{7}$

7 Disponível em: https://bit.ly/3413Ujb. Acesso em: 4 abr. 2019. 
gerido pelo Instituto de Radiodifusão Educativa da Bahia (Irdeb), na época ligado à Secretaria de Cultura do Estado da Bahia. Os cinco proponentes aprovados foram dos seguintes territórios de identidade: dois da Região Metropolitana de Salvador (sendo um o CachoeiraDoc, cujo endereço do proponente é Salvador, mas a realização do projeto é no território Recôncavo Baiano), um do Extremo Sul, um do Sudoeste Baiano e um do Sertão do São Francisco. Dentre os eventos aprovados, $80 \%$ aconteceriam no interior.

No ano seguinte, foram lançados 18 editais nas áreas de apoio às linguagens artísticas, e o CachoeiraDoc foi contemplado no edital de $n^{\circ}$ 8/2010, de Apoio à Realização de Mostras e Festivais Audiovisuais, gerido pela Diretoria de Artes Visuais e Multimeios (Dimas). O referido edital buscava apoiar até seis projetos de mostras ou festivais audiovisuais, dotados ou não de caráter competitivo, cuja duração mínima não poderia ser inferior a cinco dias.

Desde 2012, a seleção de propostas fomentadas pelo Fundo de Cultura da Bahia (FCBA) para o audiovisual se dá através do Edital Setorial do Audiovisual, gerido pela Funceb. O CachoeiraDoc realizado em 2012 foi contemplado pelo edital de $n^{0} 12 / 2012$. Esse formato, segundo a própria secretaria, objetivou estimular os diversos elos da rede produtiva do setor.

A Secretaria Estadual de Cultura tem apoiado este movimento do audiovisual e do cinema baiano, em seus mais diferentes momentos do fazer audiovisual. Ela busca estimular todos os elos produtivos deste fazer cultural. Ela hoje apoia, por exemplo, vários festivais, mostras e seminários de audiovisual e cinema na Bahia, na capital e no interior. Estes eventos tratam de muitos temas e tem possibilitado diferentes olhares, permitindo publicizar um interessante repertório audiovisual e cinematográfico para os baianos. A difusão e o debate propiciados pelos festivais, mostras e seminários são elos vitais dentro de uma política cultural voltada para o audiovisual e o cinema. Sem eles, não se alcança a abrangência necessária para o desenvolvimento consistente do audiovisual e do cinema na Bahia. (RUBIM, 2014, p. 181)

Ainda no ano de 2012 foi lançado o Edital de Eventos Calendarizados, ${ }^{8}$ política que trouxe uma importante inovação para os projetos que buscam longevidade

8 Disponível em: https://bit.ly/2GjBR6d. Acesso em: 4 abr. 2019. 
no cenário cultural. Fomos aprovados ${ }^{9}$ no edital, que financiou o CachoeiraDoc entre 2013 e 2016. ${ }^{10} \mathrm{O}$ apoio buscava conferir estabilidade à realização de eventos consolidados, com vistas à formação de calendário cultural que contemplasse diversos segmentos da cultura e diferentes regiões do estado.

Esse edital teve impacto significativo para a realização e a consolidação de importantes festivais e mostras de audiovisual que hoje compõem o calendário cultural da Bahia. [...] cinco importantes eventos obtiveram o apoio do referido edital, condição que possibilitou a realização de edições regulares: Panorama Internacional Coisa de Cinema, CachoeiraDoc, Mostra Cinema Conquista, Seminário Internacional de Cinema - Cine Futuro e Vale Curtas, totalizando um investimento de cerca $\mathrm{R} \$ 2.940 .000,00$, contribuindo, assim, para a garantia de três edições $(2013,2014,2015)$ desses importantes festivais. (VIEIRA; GUSMÃO, 2017, p. 42)

A oitava edição do CachoeiraDoc teve o apoio de mais uma edição do Edital Setorial de Audiovisual, em 2016, especificamente na área de desenvolvimento e difusão. Nesse ano concorremos também no Edital de Eventos Calendarizados de 2017 a 2019,11 no qual infelizmente não fomos contemplados, visto que teria garantido a realização no ano de 2018 e 2019. Na Tabela 1 temos os valores apoiados a cada ano pelo FCBA:

Tabela 1 - Montante de recursos recebidos pelo CachoeiraDoc via FCBA por ano

\begin{tabular}{c|c}
\hline ANO DE EXECUÇÃo & VALOR (R\$) \\
\hline 2010 & $76.500,00$ \\
\hline 2011 & $80.000,00$ \\
\hline 2012 & $93.275,00$ \\
\hline 2013 & $180.000,00$ \\
\hline 2014 & $180.000,00$ \\
\hline 2015 & $180.000,00$ \\
\hline
\end{tabular}

9 Disponível em: https://bit.ly/3nımPmz. Acesso em: 4 abr. 2019.

10 Inicialmente o edital apoiaria eventos por três anos, mas foi prorrogado por mais um ano.

11 Disponível em: https://bit.ly/3iiFF5n. Acesso em: 4 abr. 2019. 


\begin{tabular}{c|c}
\hline ANO DE EXECUÇÃo & VALOR (R\$) \\
\hline 2016 & $180.000,00$ \\
\hline 2017 & $299.967,00$ \\
\hline 2018 & não aconteceu \\
\hline 2019 & não aconteceu \\
\hline 2020 & $200.000,00$ \\
\hline
\end{tabular}

Fonte: elaborada pelos autores.

Pela trajetória do evento é perceptível a importância do financiamento público para a sua execução. Financiamento que foi sendo ampliado à medida que o próprio evento tomava uma proporção maior, ao mesmo tempo que a Secretaria de Cultura do Estado da Bahia descontinuou o lançamento de editais setoriais para a área da cultura nos anos de 2017 e 2018. Em 2017, entretanto, foram convocados praticamente todos os projetos suplentes do edital de 2016 para execução, o que como política pública é extremamente controverso, visto que esses projetos, que passaram por um processo seletivo e não foram classificados entre os primeiros colocados, ainda assim foram contemplados. A ausência de editais nesse período comprometeu o financiamento do CachoeiraDoc.

Em 2019, com cerca da metade dos recursos ${ }^{12}$ dos editais anteriores a 2016, a Secretaria da Cultura do Estado da Bahia anunciou novamente investimentos em projetos culturais da sociedade civil. Cabe ressaltar que para o setor audiovisual, foram diversas categorias divididas por origem de recursos: $\mathrm{R} \$ 5 \mathrm{mi}-$ lhões diretos do FCBA, destes R $\$ 800$ mil foram dedicados a mostras, festivais e eventos. Outros R\$15 milhões captados do Fundo Setorial do Audiovisual (FSA/ Ancine), recurso federal voltado para produção e distribuição de longa metragens e séries de TV.

As formas de financiamento federal via renúncia fiscal (Lei Rouanet) ou os mais novos editais da Secretaria do Audiovisual (SAv) seguem uma lógica comercial com retorno financeiro e/ou midiático que não condizem com a realidade de um festival de documentário na periferia do país (interior do Nordeste brasileiro). O último edital da SAv para festivais, por exemplo, exigia um retorno

12 Em 2016, o governo baiano investiu $\mathrm{R} \$ 39.620$ milhões nos editais setoriais do FCBA. Em 2019, foram $\mathrm{R} \$ 20$ milhões. 
financeiro do investimento dos projetos selecionados, algo inviável para um evento como o CachoeiraDoc.

14.1.1 Todas as ações/eventos objetos deste edital devem ter, obrigatoriamente, atividades/ações com perspectivas de geração de receitas para composição do lastro contratual e retorno do FSA, tais como: bilheteria, cursos/oficinas/workshops pagos, venda de espaço publicitário, locação de espaços físicos, venda de produtos (camisetas, bonés, livros, dvds, etc.);

14.1.2 A participação do FSA sobre as Receitas será equivalente a 50\% do percentual a que corresponder o seu investimento no total dos recursos aplicados na realização do evento. ${ }^{13}$

Como o evento que busca fomentar o documentário numa cidade do interior cuja metade da população vive com até meio salário mínimo (IBGE, 2017) conseguiria ter ao menos $50 \%$ de sua receita com bilheteria ou produtos relacionados? Como qualquer investimento na área da cultura, há projetos que não dispõem de fatores de mercado que o auxiliem nessa dinâmica, como aponta a pesquisadora Cristiane Olivieri (2004, p. 25):

No sistema capitalista, grande parte do investimento em produção de bens de toda natureza é determinado pela garantia de ressarcimento do custo do seu processo produtivo e pela possibilidade de geração de lucros através da comercialização do produto final [...] A produção cultural, contudo, nem sempre consegue obedecer essa lógica de produção de lucros [...]. Apenas parte das produções atinge a auto-sustentabilidade e uma parcela pequena consegue gerar lucros para os produtores e artistas.

Os "lucros" do CachoeiraDoc são de outra ordem e não seguem a lógica mercadológica. Daí a dificuldade de financiamento privado para o Festival. Os ganhos dizem respeito à formação, diversidade e democratização do acesso à educação e cultura para estudantes, profissionais e público, com suas possibilidades de intercâmbio e diálogo, colocando Cachoeira na rota dos festivais

13 Edital SAV/MINC/FSA de n 11/2018. Disponível em: https://bit.ly/34A1sBE. Acesso em: 5 abr. 2019. 
audiovisuais. Dizem respeito também à contribuição para a movimentação econômica do município de 33 mil habitantes que se tornou um dos principais roteiros turísticos da Bahia, mas sofre com a sazonalidade do mercado turístico, além da falta de investimentos e políticas públicas voltadas para a profissionalização e linearidade do turismo local.

Quando as políticas culturais na Bahia buscaram uma perspectiva da territorialização, em grande medida, foi para tentar mudar a realidade de determinadas regiões que apresentam diversas possibilidades de fazer cultura mas que infelizmente não conseguem ampliar ou dar continuidade a seus projetos devido à escassez de recursos. Rubim corrobora esse fato, mas se não temos incentivos reais nesse processo fica difícil dar sustentação a uma política como essa:

O processo de territorialização - assumido como política pública de cultura na Bahia - possui múltiplas dimensões e possibilidades. Por certo, uma das suas dimensões mais potentes e promissoras do projeto seja possibilitar este olhar mais amplo, diverso e plural, fazendo emergir imagens profundas e desconhecidas que conformam: a Bahia, sua rica cultura baiana e todos os baianos. (RUBIM, 2014, p. 186).

Em todo caso, vale ressaltar que o setor do audiovisual é um dos mais organizados em termos de demandas e pressão política a partir dos seus agentes. Um exemplo disso é a carta aberta ao governador Rui Costa feita pela Associação de Produtores e Cineastas da Bahia, que buscam uma resposta em relação à ausência do financiamento do setor (EM 'CARTA..., 2018), que poderia ser estratégico para a gestão estadual.

\section{Gestão de um festival}

Para a realização de um evento como um festival de cinema, há uma série de demandas da área da produção cultural que precisam ser levadas em consideração. A logística de convidados é uma das principais questões para o CachoeiraDoc, visto que, além de oferecer a possibilidade de exibição de filmes, os festivais são em especial um lugar de troca, a partir da oportunidade que as pessoas têm de entrar em contato com filmes, realizadores e outras pessoas. 
No CachoeiraDoc, em 2017, convidamos pelo menos um diretor de cada filme selecionado para a Mostra Competitiva Nacional para estar presente. Acreditamos que essa interação mais direta com os realizadores é um dos principais pontos positivos do evento, no qual ao longo dos dias de festival é possível encontrar os diversos convidados dialogando com estudantes que estão iniciando a sua formação acadêmica na área, por exemplo. Marcelo Pedroso, premiado realizador pernambucano, corrobora a importância dos diálogos no festival:

[...] eu, enquanto realizador, vou querer estar aqui sempre que o CachoeiraDoc selecionar um filme que eu dirigi. Porque é aqui que eu acho que os debates importantes estão acontecendo, sabe? E não é só um debate em si, é toda a construção que o festival faz. O gesto do festival, os filmes que ele prioriza, o tipo de arranjo que ele coloca para a comunidade, o tipo de formação de público que ele faz. Então, o CachoeiraDoc é para mim uma experiência completa: política, de vanguarda, e sempre que eu puder estrear filmes aqui vai ser com grande prazer. (PEDROSO, 2017) ${ }^{14}$

Como o evento é realizado numa cidade do interior da Bahia, temos aqui um custo agregado à logística, que é o deslocamento do aeroporto mais próximo, o de Salvador, distante 108 quilômetros. Outro gasto elevado na área de logística de convidados é o transporte dos realizadores, priorizados pelo festival, que sempre exibiu filmes que primam pela articulações entre cinema e ação sócio-política, como realizadores indígenas, por exemplo, que muitas vezes deslocam-se de aldeias distantes e de difícil acesso, mas se tornaram presença constante em todas as edições. Enfim, todo o processo de logística dos convidados, pensando desde o seu transporte na sua cidade de origem (que vai muito além do eixo Rio-São Paulo), o transporte de Salvador até Cachoeira, a sua hospedagem e alimentação durante o evento, até o seu regresso, é preciso ser feito de forma detalhada e organizada.

Essa função normalmente era de responsabilidade de um dos coordenadores de produção do projeto, tendo o apoio posterior de empresas que prestam serviços de transporte e agências de viagem, e de monitores que cuidam da

14 Entrevista de Marcelo Pedroso a Adriano Garrett (site Cine Festivais) em 2017 quando estreou o filme Por trás da linha de escudos. 
execução do receptivo dos convidados e do seu bem-estar ao longo do evento. "Essa é a área em que, podemos dizer, o produtor é o especialista. Ele não deve ter apenas a noção, mas conhecer profundamente tudo o que envolva a logística de um evento”. (LOBO, 2009, p. 29)

O público também é uma questão interessante para se pensar a gestão do festival. Zita Carvalhosa, fundadora e organizadora do Festival Internacional de Curtas-Metragens de São Paulo, em entrevista a Thaís Ravicz (2005) falou sobre os diferentes perfis de público: "Os festivais em cidades onde não existe cinema são completamente distintos dos festivais em grandes centros e cada um deve ter o seu perfil de público.” (CARVALHOSA, 2005 apud RAVICZ, 2005, p. 77)

O CachoeiraDoc é um festival segmentado de documentário numa cidade do interior do Nordeste sem hábito de cinema, apesar do Cine Theatro Cachoeirano ter sido reinaugurado em 2014, ainda não há exibição regular de filmes. A comunidade universitária da UFRB, em especial com os cursos de Cinema, Comunicação, História, Artes Visuais e Ciências Sociais do Centro de Artes Humanidades e Letras (CAHL), em Cachoeira, é o principal público do festival. Cinéfilos, estudantes, profissionais e pesquisadores de Salvador, estudantes de outros cursos de cinema do país, além dos realizadores convidados completam o conjunto frequente do evento. Como foi descrito, grande parte do público não é da cidade. Então, faz parte da produção do Festival gerenciar a demanda, mesmo que indireta, de hospedagem, alimentação e transporte desse público vindo de outros locais. Por vezes surgem caravanas, como foi o caso de um grupo de estudantes de cinema da Universidade Federal Fluminense (UFF) que precisava de hospedagens baratas e a solução encontrada foi colocar os estudantes de Cachoeira em contato com eles através das redes sociais para que fossem feitas hospedagens solidárias.

Há também um público mais disperso composto por moradores de Cachoeira e São Félix (cidade-irmã separada por uma ponte) curiosos que participam das sessões (sempre gratuitas) e oficinas. E essa presença é constantemente estimulada pelo festival, e de uma forma mais ampla por outras ações do curso de Cinema na cidade, por meio de oficinas ao longo do ano e também por atividades cineclubistas. O festival faz também sessões específicas para o público escolar, cuidando de toda a logística da vinda dos estudantes (muitas vezes da zona rural), alimentação e relação com as secretarias de educação. Algumas sessões têm mais apelo popular, como foi o caso de duas sessões lotadas em 2011 por 
torcedores do Bahia com o filme Bahêa minha vida ${ }^{15}$ ou em sessões em praça pública. Em todas as sessões, internas ou externas, os cuidados com infraestrutura, como conforto, iluminação e segurança para o público, são essenciais para garantir que a produção se mantenha invisível nos bastidores.

Outro ponto que merece destaque na gestão é a contratação de parte dos estudantes do curso de Cinema e Audiovisual da UFRB como monitores, júri, e comissão de seleção do CachoeiraDoc. Acreditamos na importância desse processo para a formação e qualificação desses discentes, como um projeto de extensão junto à comunidade que possibilita o compartilhamento, com o público externo, do conhecimento adquirido por meio do ensino e da pesquisa desenvolvidos na instituição, além de uma experiência de trabalho na área, já que estágios e trabalhos na cidade de Cachoeira não dão conta da demanda profissionalizante da comunidade estudantil. ${ }^{16}$ A cada edição do CachoeiraDoc promovemos chamadas públicas para a monitoria, em diferentes áreas, e encontros com os monitores para treinamento e alinhamento das funções. Em geral existem monitores nas áreas do registro audiovisual, registro fotográfico, receptivo dos convidados, apoio da estrutura técnica e apoio no cinema. Podemos perceber um exemplo desse aprendizado e desse processo formativo na carta de intenção de um dos candidatos para a monitoria no ano de 2017:

\begin{abstract}
Acredito que trabalhar no festival me proporciona maior amadurecimento como fotógrafo, e um encaminhamento maior para o mercado de trabalho. No evento do ano passado, o ambiente de troca e aprendizado me fez crescer bastante no pessoal e profissional. Ficaria muito feliz em contribuir criativamente este ano. (INSCRIÇÕES..., 2017)
\end{abstract}

Outro fator importante para gestão de um festival, bem como de outros eventos na área cultural, é o relacionamento com prestadores de serviço locais e empresas, assim como apoiadores e parceiros institucionais que trazem recursos além dos financeiros ao evento. Cabe ressaltar a importância dada pela produção do Festival à utilização de mão de obra local para realização de parte das

15 Disponível em: http://www.cachoeiradoc.com.br/2011/sessoes-especiais.html. Acesso em: 18 abr. 2019.

16 Mais informações sobre a importância desse processo formativo no texto "Memórias de uma árvore empassarinhada: formação e extensão no CachoeiraDoc", de Ana Rosa Marques, neste livro. 
atividades do evento, como era o caso do artesão Louco Filho, que criava o troféu da Mostra Competitiva, por exemplo.

A UFRB tem papel fundamental na realização do festival, em conjunto com a Ritos Produções. Além de possibilitar o apoio em algumas edições através da cessão de transporte, passagens aéreas e diárias para convidados, a universidade cede prestígio institucional ao evento, que é um projeto de extensão, o que possibilita certificar os participantes e utilizar equipamentos e instalações do CAHL. Essa parceria potencializa a capacidade de diálogo da universidade com a sociedade e com a comunidade local, contribuindo para que a instituição desenvolva plenamente sua capacidade de ser um agente privilegiado de formação cultural.

A cidade de Cachoeira, por meio da prefeitura municipal e da Secretaria de Cultura e Turismo, também é parceira institucional importante. Ao longo das últimas oito edições do festival, tratamos com diferentes gestores municipais, sempre buscando colocar a gestão da cultura municipal como parceira na promoção do evento através de cessão de uso do espaço público e apoio de iluminação e segurança, além de intermediação da relação com escolas do município. Essa parceria se estreitou com a reinauguração do Cine Theatro Cachoeirano, administrado pela prefeitura, em 2014. "O espaço, tombado pelo Instituto do Patrimônio Histórico e Artístico Nacional (IPHAN), em 1937, estava desativado há cerca de 20 anos e teve investimento em torno de $\mathrm{R} \$ 6$ milhões para ser reativado”. (CINE-THEATRO..., 2014)

As primeiras edições do CachoeiraDoc tinham as suas projeções no Auditório do CAHL-UFRB, um espaço amplo e confortável. Mas realizar um festival de cinema numa sala de cinema de rua numa cidade do interior foi algo que nos fez repensar inclusive a dinâmica da programação do evento. Um cinema que fica numa das ruas mais movimentadas e boêmias da cidade de Cachoeira, com tudo o que há de bom e ruim nisso.

A transposição do festival para uma sala de cinema também trouxe novas possibilidades técnicas. A exibição pôde contar com o digital cinema package (DCP), formato utilizado amplamente na distribuição e na exibição do cinema digital no mundo, tanto nos festivais de cinema quanto nos circuitos comerciais. Infelizmente o equipamento que permite tal exibição precisa de melhores instalações e manutenção no Cine Theatro Cachoeira e deixou de funcionar em 2017, com apenas três anos de uso, apesar da intervenção direta do CachoeiraDoc numa tentativa de conserto e manutenção do equipamento do Cine Theatro. 
A edição de 2017, retomou a exibição em formatos digitais mais comuns dos arquivos e projetores da universidade.

Na discussão sobre formatos analógicos e digitais para o cinema, a qual não iremos adentrar, cabe referenciar o que Marcelo Ikeda disse em entrevista à pesquisadora Thaís Alves Ravicz:

A vantagem da projeção digital pro documentário é que, muitas vezes, o documentário é todo captado em vídeo, então, o custo do transfer às vezes inviabiliza o valor do documentário, tem um peso muito significativo no orçamento. Então, se a pessoa puder fazer uma cópia em HD, que vai ser caro, mas muito mais barato do que o transfer, se ela puder projetar isso em digital, vai ser uma economia muito grande. Alguns documentários só foram exibidos em cinema por conta da projeção digital. Comparando com os filmes de ficção, isso teve uma repercussão bastante expressiva. (IKEDA, 2005 apud RAVICZ, 2005, p. 40)

Cabe também citar aqui como a mudança tecnológica foi importante nesse processo de oito edições de realização de um festival. Nos primeiros eventos, para submeter um filme à curadoria da Mostra Competitiva era necessário encaminhar, via postal, dois CDs ou DVDs com os arquivos dos filmes, além de um CD com fotos do diretor e still. A partir de 2014, com a popularização e avanços tecnológicos, já foi possível submeter os filmes por meio de link de sites de hospedagem de arquivos ou vídeos, normalmente com senha, para visualização por streaming. Isso facilita não apenas a inscrição dos produtores dos filmes, que assim a fazem de forma não onerosa, como também o processo de produção e curadoria, que pode ser mais dinâmico e com pessoas em diferentes localidades, tendo em vista que não é mais necessário encaminhar as cópias físicas através de vários CDs.

Como pode ser visualizado no Gráfico 1, a tecnologia colaborou com o aumento do número de inscritos na Mostra Competitiva do Festival. Entre 2013 e 2014, quando houve a mudança de submissão física para digital, tivemos um aumento de $38 \%$ nas inscrições. 


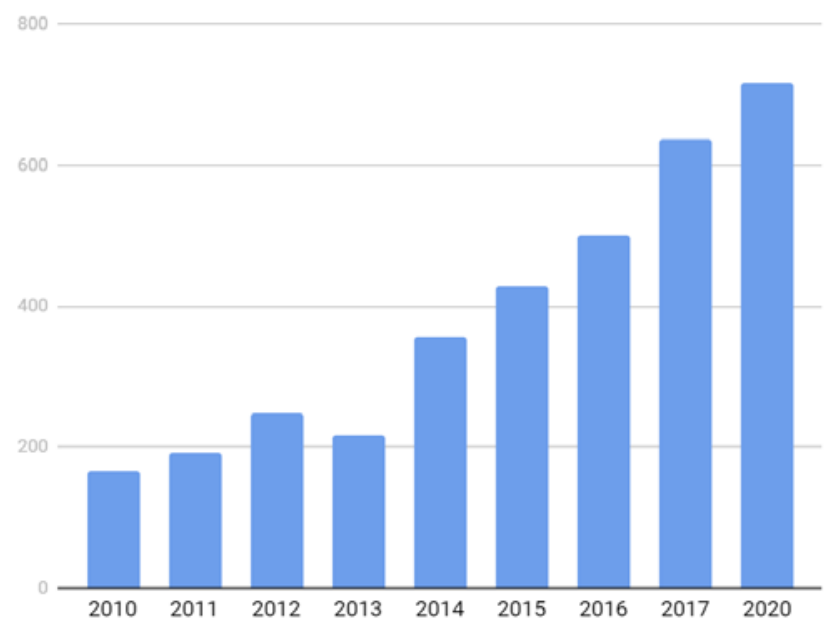

Gráfico 1 - Filmes inscritos na Mostra Competitiva ao longo dos anos

Fonte: elaborado pelos autores.

\section{Considerações}

O CachoeiraDoc acontece em um dos raros cinemas de rua em operação no interior do estado da Bahia, reunindo estudantes, pesquisadores, cineastas, artistas, comerciantes, professoras, para assistir filmes de todo o Brasil, debater e pensar a vida através do cinema. Ao mesmo tempo que desenvolve projetos de extensão para as comunidades locais, o CachoeiraDoc faz de Cachoeira um lugar de encontros e intercâmbios, de onde se tem interrogado e instigado o cinema produzido no Brasil, colocando a Bahia na rota dos eventos cinematográficos mais respeitados do país.

Depois de oito edições do Festival podemos concluir que os encontros são potencializados pelo fato da cidade ser pequena, visto que nos dias em que o público-turista está na cidade muito provavelmente estará reunido em poucos lugares diferentes. Então, para além dos debates nas salas de exibição e oficinas, assistir a um show ou partilhar uma comida também faz parte dos atrativos do evento. As festas dentro do festival foram momentos que desdobravam os contatos e a troca de experiências, momentos de apresentar a riqueza musical da 
região e de fazer dialogar a temática do evento com outras manifestações artísticas.

Do futuro pouco se sabe, e nesse momento com a emergência da extrema direita no poder e desmonte das políticas culturais, menos ainda. O Plano Nacional de Cultura, o primeiro a ser feito num período democrático no Brasil, tem a sua previsão de encerramento no ano de 2020, mas já se sabe que uma série de metas não conseguirão ser atingidas devido aos períodos de instabilidades e ausências que vivemos nas políticas culturais. Há algumas metas desse plano que tratam especificamente do audiovisual, como a de número 27: "27\% de participação dos filmes brasileiros na quantidade de bilhetes vendidos nas salas de cinema”. (27\% DE..., 2017) No caso dos eventos há uma meta, a de número 24, que trata especificamente da produção e a circulação de espetáculos e atividades artísticas, tais como festivais, mostras, exposições, espetáculos e atividades de artes visuais, teatro, dança, circo, música e outras linguagens artísticas. A meta busca uma não concentração dos recursos apenas nos grandes centros urbanos, mas até o momento, pelo menos na região Nordeste, só foi alcançado um percentual de $12 \%$ de municípios com projetos fomentados com recursos federais, ou seja, 221 municípios de um total previsto de 1.076 a cada ano. (META 24..., 2018) Espera-se pela volta dessas políticas públicas o quanto antes para que perspectivas pluralistas como o CachoeiraDoc possam continuar sonhando e executando um novo mundo através do cinema.

O CachoeiraDoc retoma as suas atividades em 2020 após dois anos de pausa, mas sabemos das possibilidades de inconstâncias das políticas culturais. $\mathrm{O}$ projeto que foi contemplado pelo FCBA seria realizado entre os dias 26 a 31 de maio de 2020, mas devido à pandemia de Covid-19 o evento não pôde ser feito de forma presencial. Nas datas previstas foi feita uma atividade de forma remota com exibição de filmes e dois debates com as curadoras e curadores: Festival Impossível, Curadoria Provisória ${ }^{17}$. Os números foram expressivos: 6.300 visualizações dos filmes durante 15 dias e 1.200 pessoas participando dos debates. Será que o on-line veio para ficar de alguma forma como uma alternativa? A nona edição acontece também de forma remota em dezembro de 2020, mas as reflexões sobre esta forma de fazer um festival de cinema sem o encontro presencial com o público fica para uma outra ocasião.

17 Disponível em: http://www.cachoeiradoc.com.br/festivalimpossivel/. Acesso em: 25 jun. 2020 
Reiteramos de toda forma a necessidade e importância dos encontros presenciais na cidade de Cachoeira e em outras cidades do interior da Bahia e de outras cidades às margens da produção cultural, contribuindo com a difusão do audiovisual brasileiro e a diversidade de encontros através do cinema.

\section{Referências}

27\% DE participação dos filmes brasileiros na quantidade de bilhetes vendidos nas salas de cinema. Brasília, DF: Secretaria Especial da Cultura, 2017. Disponível em: http://pnc.cultura.gov.br/category/ metas/27/. Acesso em: 5 abr. 2019.

ALENCAR, Miriam. O cinema em festivais e os caminhos do curtametragem no Brasil. Rio de Janeiro: ArteNova, 1978.

BEZERRA, Laura; ROCHA, Renata. Políticas de audiovisual. In: RUBIM, Antonio Albino Canelas; ROCHA, Renata (org.). Politicas culturais. Salvador: Edufba, 2012. p. 113-137.

CINE-THEATRO Cachoeirano, na BA, é reinaugurado após 20 anos fechado. G1 Bahia, Salvador, 25 jun. 2014. Disponível em: https://glo. bo/2GjaUzS. Acesso em: 5 abr. 2019.

CÔRREA, Paulo Vitor Luz. Os festivais audiovisuais brasileiros em 2017: geografia e virtualização. [S. l.: s. n.], 2018. Disponível em: https:// bit.ly/33WSnBs. Acesso em: 19 abr. 2019.

COSTA, Mannuela Ramos da. Cinema, desenvolvimento e o papel dos governos estaduais no Brasil. Revista Latinoamericana de Ciencias de la Comunicación, São Paulo, v. 10, n. 19, p. 130-139, 2013.

COTRIM, Tamara Chéquer. Festivais e mostras de cinema na Bahia contemporânea: memória e processos de formação cultural. 2017. Dissertação (Mestrado em Memória: Linguagem e Sociedade) Universidade Estadual do Sudoeste da Bahia, Vitória da Conquista, 2017.

EM 'CARTA Aberta', Associação de Produtores e Cineastas da Bahia cobra Editais ao governador. Interior da Bahia, [s. l.], 7 jun. 2018. Disponível em: https://bit.ly/3n2t8Xk. Acesso em: 5 abr. 2019. IBGE. Cidades: Cachoeira. Rio de Janeiro: IBGE, 2017. Disponível em: https://bit.ly/36dwJeR . Acesso em: 25 jun. 2020. 
INSCRIÇÕES até dia 10/8 para colaboradores do CachoeiraDoc. Cachoeira: CachoeiraDoc, 2017. Disponível em: https://bit.ly/2G9On8J. Acesso em: 5 abr. 2019.

LIMA, Hanayana Brandão G. F. Políticas culturais na Bahia: gestões de Paulo Souto (2003-2007) e Jaques Wagner (2007-2009). Dissertação (Mestrado em Cultura) - Universidade Federal da Bahia, Salvador, 2011.

LOBO, Carla. Diário de produção: relatos, dicas, experiências e casos de quem aprendeu a produção cultural na prática. Belo Horizonte: [s. n.], 2009.

MARSON, Melina Izar. O cinema da retomada: Estado e cinema no Brasil da dissolução da Embrafilme à criação da Ancine. 2006. 2002 p. Dissertação (Mestrado em Cultura e Sociedade) - Universidade Estadual de Campinas, Campinas, 2002. Disponível em: http:// repositorio.unicamp.br/handle/REPOSIP/281517. Acesso em: 26 set. 2020.

META 24: 60\% dos municípios de cada macrorregião do país com produção e circulação de espetáculos e atividades artísticas e culturais fomentados com recursos públicos federais. Brasília, DF: Secretaria Especial da Cultura, 2018. Disponível em: http://pnc.cultura.gov. br/2017/07/28/meta-24/. Acesso em: 5 abr. 2019

OLIVIERI, Cristiane Garcia. Cultura neoliberal: leis de incentivo como política pública de cultura. São Paulo: Escrituras, 2004.

PEDROSO, Marcelo. "Só a partir da escuta é que podemos pensar numa possibilidade de transformação”. [Entrevista cedida a] Adriano Garrett. Cine Festivais, São Paulo, 12 set. 2017. Disponível em: https:// bit.ly/3kP7bJ2. Acesso em: 18 abr. 2019.

RAVICZ, Thaís Alves. Novos caminhos para o cinema documentário: a redescoberta do gênero no século XXI. 2005. Monografia (Bacharel em Comunicação Social) - Universidade Federal do Rio de Janeiro, Rio de Janeiro, 2005. Disponível em: https://bit.ly/30cK833. Acesso em: 5 abr. 2019.

RUBIM, Antonio Albino Canelas. Políticas culturais na Bahia contemporânea. Salvador: Edufba, 2014. 
RUBIM, Antonio Albino Canelas. Discurso de Albino Rubim (transmissão de cargo - 2015). Salvador: Secult, 7 jan. 2015. Disponível em: https://bit.ly/3mWn4zu. Acesso em: 18 abr. 2019.

RUBIM, Antonio Albino Canelas. Políticas culturais no Brasil: tristes tradições, enormes desafios. In: RUBIM, Antonio Albino Canelas; BARBALHO, Alexandre (org.). Políticas culturais no Brasil. Salvador: Edufba, 2007. p. 11-36.

UFRB. Curso de cinema e audiovisual com ênfase em documentário. Cruz das Almas: UFRB, [200-]. Projeto pedagógico. Disponível em: https://bit.ly/3331fGv. Acesso em: 16 abr. 2019.

VIEIRA, Mariella Pitombo; GUSMÃO, Milene. O mercado audiovisual brasileiro, o circuito alternativo de exibição, as mostras e festivais de cinema na Bahia contemporânea. Ciências Sociais Unisinos, São Leopoldo, v. 53, n. 1, p. 36-45, 2017. Disponível em: https://bit. ly/30dldfX. Acesso em: 5 abr. 2019. 